\title{
Clinical Profile of Neonatal Meningitis and Analysis of Various Factors for Prognostic Significance
}

\author{
Dr. L.Kalpana \\ Associate professor,department of paediatrics,meenakshi medical college\&research institute, MAHER \\ university, tamilnadu,india
}

\begin{abstract}
Aims and Objectives
- To analyse the clinical profile of acute bacterial meningitis in newborn period.

- To analyse the risk factors in neonatal meningitis with respect to outcome

Material and Methods

Study design : Descriptive study

Study Period : June-2011-May 2012

Study Place : Meenakshi medical college\&research institute

Study Population: All babies of both sexes belonging to Neonatal period, admitted in newborn ward in the institute with strong clinical suspicion of sepsis or meningitis.

Sample size: 40 neonates fulfilling the inclusion criteria were recruited over a period of one year.

Results: The male female ratio was 1.4:1. There were 29 (72.5\%) term and 11 (27.5\%) preterm in the study population. Majority of them 25(60\%) had birth weight of $<2.5 \mathrm{~kg}$ while $15(40 \%)$ had a birth weight of $\geq 2.5$ kg.Among 14 neonates who died 12(85.7\%) neonates had and 2 (14.3\%) did not have respiratory distress. $P$ value 0.04 for presence of respiratory distress was statistically significant

Analysis unveiled that bronchopneumonia was the most important risk factor predicting outcome in neonatal meningitis; it was associated with 10 times increased risk of mortality. Other variables were not statistically significant.
\end{abstract}

Keywords: newborn, meningitis, sepsis, mortality, convulsion.

\section{Introduction}

Bacterial sepsis and meningitis continue to be major causes of morbidity and mortality in the newborn, despites improvement in antimicrobial therapy, advances in neonatal life support measure and prompt recognition of perinatal risk factor for infection. Neonatal meningitis can be devastating and surviving infants can have significant neurological sequelae as a consequence of CNS involvement, septic shock, hypoxia, secondary to severe parenchymal involvement and persistent pulmonary hypertension.

Acute bacterial meningitis continues to be a major public health problem. Mortality in the acute stage is high, survivors are often left with crippling neuro developmental sequelae. Prognosis is largely determined by early diagnosis and prompt institution of specific antimicrobial therapy

\section{Aims And Objectives}

- To analyse the clinical profile of acute bacterial meningitis in newborn period.

- To analyse the risk factors in neonatal meningitis with respect to outcome.

3.1 Study design

3.2 Study Period

3.3 Study Place

3.4 Study Population
3.Material And Methods

: Descriptive study

: June - 2011 - May 2012

: Meenakshi medical college\&research institute

: All babies of both sexes belonging to Neonatal period, admitted in newborn ward in the institute with strong clinical suspicion of sepsis or meningitis.

\subsection{Inclusion criteria}

Clinical features suggestive of sepsis/meningitis in the form of irritability, lethargy, poor feeding, convulsions, with or without fever and with or without bulging anterior fontanelle and atleast two of five following positive CSF laboratory test.

1) Spinal fluid pleocytosis $>5$ polymorphs $/ \mathrm{mm}^{3}$

2) Decreased spinal fluid sugar $<40 \mathrm{mg} \%$ (or) $<50 \%$ of a simultaneously obtained blood sugar

3) Spinal fluid protein $>120 \mathrm{mg} \%$

4) Definite bacteria on stained smear 
5) Positive spinal fluid culture

\subsection{Exclusion criteria}

- Congenital malformation of spinal cord/ central nervous system.

- Birth Asphyxia.

\subsection{Sample size}

40 neonates fulfilling the above inclusion criteria were recruited over a period of one year.

\subsection{Manoeuver}

All neonates of both sexes presenting with clinical features of meningitis / sepsis admitted in the newborn unit during the study period were subjected to detailed physical examination and CSF analysis. 40 neonates fulfilled the criteria for bacterial meningitis and were recruited. These neonates were followed up for clinical outcome.

Sepsis screening done for the study population included hematological investigation - complete blood count, peripheral smear, biochemical investigations - blood sugar, calcium, electrolytes and microbiological investigation including non enteric culture

Radiological investigation done included chest radiograph and cranial ultrasonogram. The presence of ventriculitis, ventriculomegaly and subdural effusion were noted.

The clinical progression of the disease and treatment during the stay in the hospital were monitored and immediate complications if any were looked for.

Outcome measure noted were death due to the illness and recovery with without immediate complications.

Death due to illness was defined as the newborn dying at any time during hospital stay.

Recovery without complications was defined as neonates who showed improvement in the form of good activity, feeding, thermostability, absence of seizure, without tetraventricular hydrocephalus and neurological deficit.

Recovery with immediate complications was defined as neonates who showed neurological deficit, abnormal posture, ultrasound cranium showed evidence of tetraventricular hydrocephalus and minimal subdural effusion

\section{Results And Analysis \\ 4.1 Demographic profile of Neonatal meningitis as follows}

TABLE - 1

\begin{tabular}{|l|l|l|}
\hline Sl.No & Variables & $\mathbf{N}=\mathbf{4 0}$ \\
\hline 1. & Age $<7$ days & $12(30 \%)$ \\
& \multicolumn{7}{|c|}{ days } & $28(70 \%)$ \\
\hline 2. & Male & $23(57.5 \%)$ \\
& Female & $17(42.5 \%)$ \\
\hline 3. & Term & $29(72.5 \%)$ \\
& Preterm & $11(27.5 \%)$ \\
\hline 4. & Birth weight & \\
& $<2.5 \mathrm{~kg}$ & $25(60 \%)$ \\
& $>2.5 \mathrm{~kg}$ & $15(40 \%)$ \\
\hline
\end{tabular}

Neonates who aged less than 7 days were $12(30 \%)$ and more than 7 days were 28(70\%). Out of 40 neonates $23(57.5 \%)$ were male and $17(42.5 \%)$ were female. The male female ratio was 1.4:1. There were $29(72.5 \%)$ term and $11(27.5 \%)$ preterm in the study population. Majority of them $25(60 \%)$ had birth weight of $<2.5 \mathrm{~kg}$ while $15(40 \%)$ had a birth weight of $\geq 2.5 \mathrm{~kg}$. 


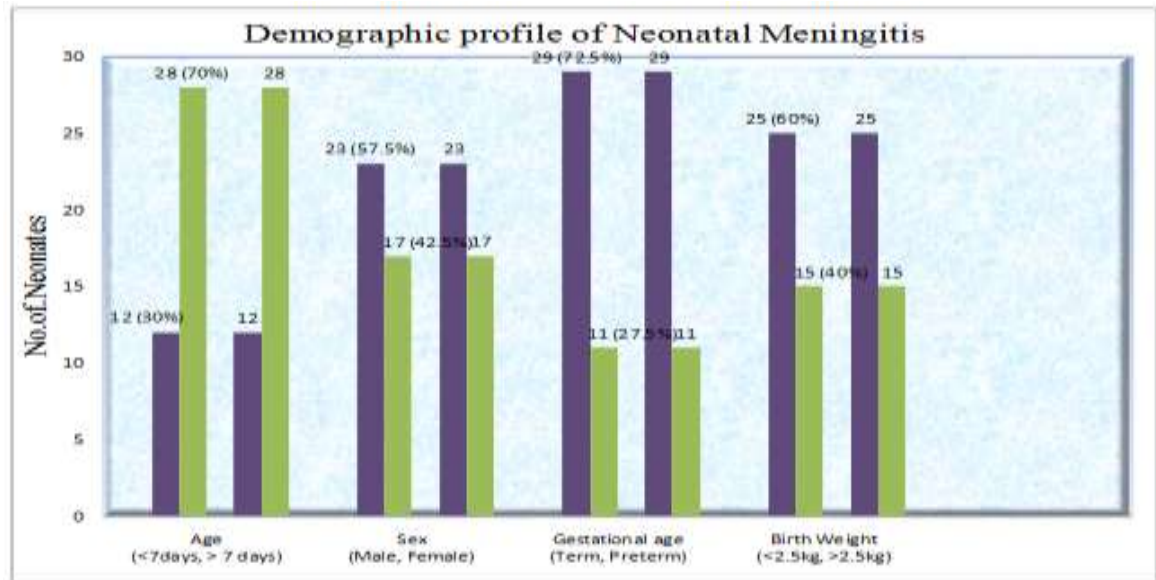

Fig: 1

\subsection{Profile of clinical presentation of Neonatal Meningitis}

TABLE - 2

\begin{tabular}{|l|l|l|}
\hline Sl.No & Clinical Features & $\mathbf{N}=\mathbf{4 0}$ \\
\hline & Symptoms & \\
\hline 1. & Lethargy & $37(92.5 \%)$ \\
\hline 2. & Poor feeding & $36(90 \%)$ \\
\hline 3. & Seizure & $27(67.5 \%)$ \\
\hline 4. & Fever & $24(60 \%)$ \\
\hline 5. & Abdomen Distension & $14(35 \%)$ \\
\hline 6. & Apnea Spell & $13(32.5 \%)$ \\
\hline 7. & Irritability & $8(26 \%)$ \\
\hline & Clinical Signs & \\
\hline 8. & Absent Neonatal Reflexes & $27(82.5 \%)$ \\
\hline 9. & Bulging Anterior fontanelle & $21(52.5 \%)$ \\
\hline 10 & Organomegaly & $18(45 \%)$ \\
\hline 11. & Pallor & $13(32.5 \%)$ \\
\hline 12. & Jaundice & $7(17.5 \%)$ \\
\hline
\end{tabular}

Most of the neonates presented with lethargy 37 (92.5\%), poor feeding 36 (90\%), seizures $27(67.5 \%)$ and fever $24(60 \%)$. While other clinical symptoms like abdominal distension, apnea spell and irritability were present in $14(35 \%), 13(32.5 \%)$ and 8 (26\%) neonates respectively.

Among the study population neonatal reflex was not elicitable in $27(82.5 \%)$ and bulging anterior fontanelle was found in $21(52.5 \%)$ neonates. Organomegaly was present in $18(45 \%)$ neonates. Pallor and jaundice were present only in few neonates $13(32.5 \%)$ and $7(12.5 \%)$ respectively.

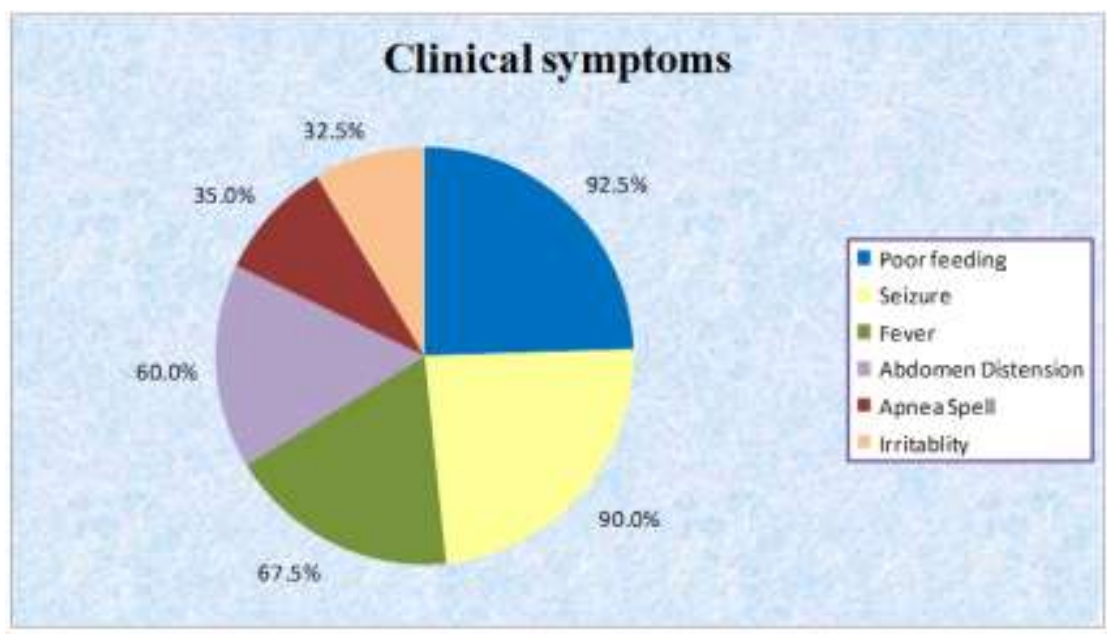

Fig 2: Profile of clinical Presentation of Neonatal Meningitis 


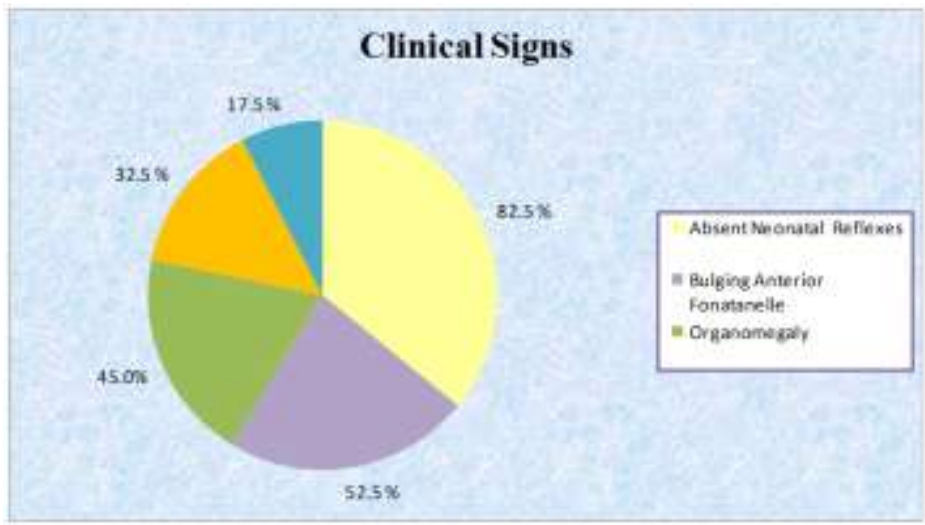

Fig: 3

The neonates who recovered with (or) without any immediate complications were compared to the group of neonates who died to identify various risk factors. 34 variables were identified, of which 20 were clinical findings and 14 were laboratory findings. Those factors were analysed by univariate analysis for significance.

5.Various factors analysed for prognostic significance by uinivariate analysis as follows 5.1 Demographic Profile

TABLE - 3

\begin{tabular}{|c|c|c|c|c|c|c|c|}
\hline \multirow{4}{*}{ Variable } & \multirow{4}{*}{ Category } & \multirow{2}{*}{\multicolumn{4}{|c|}{ Recovered }} & \multirow{4}{*}{$\begin{array}{l}\text { Total } \\
(n=40)\end{array}$} & \multirow{4}{*}{$P$ Value } \\
\hline & & & ered & \multicolumn{2}{|c|}{ Expired } & & \\
\hline & & \multicolumn{2}{|c|}{\begin{tabular}{l|l} 
No & $\%$ \\
\end{tabular}} & \multirow{2}{*}{\multicolumn{2}{|c|}{\begin{tabular}{l|l} 
No & $\%$ \\
$(n=14)$ \\
\end{tabular}}} & & \\
\hline & & \multicolumn{2}{|c|}{$(n=26)$} & & & & \\
\hline \multirow{3}{*}{$\begin{array}{l}\text { Age (onset of } \\
\text { illness) }\end{array}$} & $<7$ days & 10 & $38.5 \%$ & \multicolumn{2}{|c|}{$(\mathbf{n}=14)$} & 12 & $0.048 *$ \\
\hline & 7-14days & 9 & $34.6 \%$ & 4 & $28.6 \%$ & 13 & (Sig) \\
\hline & $>14$ days & 7 & $26.9 \%$ & 8 & $57.1 \%$ & 15 & \\
\hline \multirow[t]{2}{*}{ Sex } & Male & 15 & $57.7 \%$ & 8 & $57.1 \%$ & 23 & $1.00 * *$ \\
\hline & Female & 11 & $42.3 \%$ & 6 & $42.9 \%$ & 17 & (NS) \\
\hline \multirow[t]{3}{*}{ Mode of Delivery } & LSCS & 6 & $23.1 \%$ & 1 & $7.1 \%$ & 7 & $0.40 \#$ \\
\hline & Normal & 20 & $76.9 \%$ & 11 & $78.6 \%$ & 31 & (NS) \\
\hline & NK & 0 & $0 \%$ & 2 & $14.3 \%$ & 2 & \\
\hline \multirow{2}{*}{$\begin{array}{l}\text { Risk Factor } \\
\text { (MRO>18 Hours) }\end{array}$} & Present & 3 & $11.5 \%$ & 1 & $7.1 \%$ & 4 & $1.00 \#$ \\
\hline & $\begin{array}{l}\text { Absent } \\
\text { NK }\end{array}$ & $\begin{array}{l}23 \\
0\end{array}$ & $\begin{array}{l}88.5 \% \\
0 \%\end{array}$ & $\begin{array}{l}11 \\
2\end{array}$ & $\begin{array}{l}78.6 \% \\
14.3 \%\end{array}$ & $\begin{array}{l}34 \\
2\end{array}$ & (NS) \\
\hline \multirow{3}{*}{ Postnatal fever } & Present & 1 & $3.8 \%$ & 0 & $0 \%$ & 1 & $1.00 \#$ \\
\hline & Absent & 25 & $96.2 \%$ & 12 & $85.7 \%$ & 37 & $(\mathrm{NS})$ \\
\hline & NK & 0 & $0 \%$ & 2 & $14.3 \%$ & 2 & \\
\hline \multirow[t]{2}{*}{ Gestational Age } & Term & 20 & $76.9 \%$ & 9 & $100 \%$ & 29 & $0.02 \#$ \\
\hline & Preterm & 6 & $23.1 \%$ & 5 & $0 \%$ & 11 & (Sig) \\
\hline \multirow[t]{2}{*}{ Birth Weight } & $<2500$ & 17 & $65.4 \%$ & 8 & $57.1 \%$ & 25 & $0.30 \#(\mathrm{NS})$ \\
\hline & $\geq 2500$ & 9 & $34.6 \%$ & 6 & $42.9 \%$ & 15 & \\
\hline \multirow{3}{*}{$\begin{array}{l}\text { Duration of } \\
\text { Treatment }\end{array}$} & $<7$ days & 8 & 30.8 & 13 & $92.9 \%$ & 21 & $0.0005 *$ \\
\hline & 7-14days & 13 & 50.0 & 1 & $7.1 \%$ & 14 & (Sig) \\
\hline & $>14$ days & 5 & 19.2 & 0 & $0 \%$ & 5 & \\
\hline \multirow{3}{*}{$\begin{array}{l}\text { Pre treatment with } \\
\text { antibiotics }\end{array}$} & No & 19 & $73.1 \%$ & 7 & $50.0 \%$ & 26 & $0.26 *$ \\
\hline & $<48 \mathrm{hrs}$ & 3 & $11.5 \%$ & 4 & $28.6 \%$ & 7 & (NS) \\
\hline & $>48 \mathrm{hrs}$ & 4 & $15.4 \%$ & 3 & $21.4 \%$ & 7 & \\
\hline
\end{tabular}

Of those neonates who presented beyond 14 days of life 7(26.9\%) recovered, while $8(57.1 \%)$ expired. The $p$ value 0.048 for age of presentation more than 14 days was statistically significant for mortality. 


\subsection{Clinical Profile}

TABLE -4

\begin{tabular}{|c|c|c|c|c|c|c|c|}
\hline \multirow{3}{*}{ Variable } & \multirow{3}{*}{ Category } & \multicolumn{2}{|c|}{ Recovered } & \multicolumn{2}{|c|}{ Expired } & \multirow{3}{*}{$\begin{array}{l}\text { Total } \\
(n=40)\end{array}$} & \multirow{3}{*}{ P Value } \\
\hline & & No & $\%$ & No & $\%$ & & \\
\hline & & \multicolumn{2}{|c|}{$(\mathbf{n}=\mathbf{2 6})$} & \multicolumn{2}{|c|}{$(n=14)$} & & \\
\hline Poor Feeding & $\begin{array}{l}\text { Present } \\
\text { Absent }\end{array}$ & $\begin{array}{l}23 \\
3\end{array}$ & $\begin{array}{l}88.5 \% \\
11.5 \%\end{array}$ & $\begin{array}{l}13 \\
1\end{array}$ & $\begin{array}{l}92.9 \% \\
7.1 \%\end{array}$ & $\begin{array}{l}36 \\
4\end{array}$ & $1.00 \#(\mathrm{NS})$ \\
\hline Lethargy & $\begin{array}{l}\text { Present } \\
\text { Absent }\end{array}$ & $\begin{array}{l}24 \\
2\end{array}$ & $\begin{array}{l}92.3 \% \\
7.7 \%\end{array}$ & $\begin{array}{l}13 \\
1\end{array}$ & $\begin{array}{l}92.9 \% \\
7.1 \%\end{array}$ & $\begin{array}{l}37 \\
3\end{array}$ & $1.00 \#(\mathrm{NS})$ \\
\hline Seizure & $\begin{array}{l}\text { Present } \\
\text { Absent }\end{array}$ & $\begin{array}{l}17 \\
9\end{array}$ & $\begin{array}{l}65.4 \% \\
34.6 \%\end{array}$ & $\begin{array}{l}10 \\
4\end{array}$ & $\begin{array}{l}71.4 \% \\
28.6 \%\end{array}$ & $\begin{array}{l}27 \\
13\end{array}$ & $1.00 \#(\mathrm{NS})$ \\
\hline Fever & $\begin{array}{l}\text { Present } \\
\text { Absent }\end{array}$ & $\begin{array}{l}14 \\
12\end{array}$ & $\begin{array}{l}53.8 \% \\
46.2 \%\end{array}$ & $\begin{array}{l}10 \\
4\end{array}$ & $\begin{array}{l}71.4 \% \\
28.6 \%\end{array}$ & $\begin{array}{l}24 \\
16\end{array}$ & $\begin{array}{ll}0.46 & * * \\
\text { (NS) } & \end{array}$ \\
\hline Respiratory Distress & $\begin{array}{l}\text { Present } \\
\text { Absent }\end{array}$ & $\begin{array}{l}12 \\
4\end{array}$ & $\begin{array}{l}46.2 \% \\
53.8 \%\end{array}$ & $\begin{array}{l}12 \\
2\end{array}$ & $\begin{array}{l}85.7 \% \\
14.3 \%\end{array}$ & $\begin{array}{l}26 \\
6\end{array}$ & 0.04 \# (Sig) \\
\hline $\begin{array}{l}\text { Abdomen } \\
\text { Distension }\end{array}$ & $\begin{array}{l}\text { Present } \\
\text { Absent }\end{array}$ & $\begin{array}{l}6 \\
20\end{array}$ & $\begin{array}{l}23.1 \% \\
76.9 \%\end{array}$ & $\begin{array}{l}8 \\
6\end{array}$ & $\begin{array}{l}57.1 \% \\
42.9 \%\end{array}$ & $\begin{array}{l}14 \\
36\end{array}$ & 0.04 \# (Sig) \\
\hline Apnea Spell & $\begin{array}{l}\text { Present } \\
\text { Absent }\end{array}$ & $\begin{array}{l}7 \\
19\end{array}$ & $\begin{array}{l}26.9 \% \\
73.1 \%\end{array}$ & $\begin{array}{l}6 \\
8\end{array}$ & $\begin{array}{l}42.9 \% \\
57.1 \%\end{array}$ & $\begin{array}{l}13 \\
27\end{array}$ & $0.48 \#(\mathrm{NS})$ \\
\hline Irritability & $\begin{array}{l}\text { Present } \\
\text { Absent }\end{array}$ & $\begin{array}{l}3 \\
23 \\
\end{array}$ & $\begin{array}{l}11.5 \% \\
88.5 \%\end{array}$ & $\begin{array}{l}5 \\
9 \\
\end{array}$ & $\begin{array}{l}35.7 \% \\
64.3 \%\end{array}$ & $\begin{array}{l}8 \\
32 \\
\end{array}$ & $0.10 \#$ (NS) \\
\hline Neonatal Reflex & $\begin{array}{l}\text { Present } \\
\text { Absent }\end{array}$ & $\begin{array}{l}7 \\
19\end{array}$ & $\begin{array}{l}26.9 \% \\
73.1 \%\end{array}$ & $\begin{array}{l}0 \\
14\end{array}$ & $\begin{array}{l}0 \% \\
100 \%\end{array}$ & $\begin{array}{l}7 \\
33\end{array}$ & $0.07 \#(\mathrm{NS})$ \\
\hline Anterior Fontanelle & $\begin{array}{l}\text { Normal } \\
\text { Full bulging } \\
\text { depressed }\end{array}$ & $\begin{array}{l}14 \\
11 \\
1\end{array}$ & $\begin{array}{l}53.8 \% \\
42.3 \% \\
3.8 \%\end{array}$ & $\begin{array}{l}3 \\
10 \\
1\end{array}$ & $\begin{array}{l}21.4 \% \\
71.4 \% \\
7.1 \%\end{array}$ & $\begin{array}{l}17 \\
21 \\
2\end{array}$ & $\begin{array}{l}0.14 @ 0 \\
(\mathrm{NS})\end{array}$ \\
\hline Organomegaly & $\begin{array}{l}\text { Absent } \\
\text { Present }\end{array}$ & $\begin{array}{l}17 \\
9 \\
\end{array}$ & $\begin{array}{l}65.4 \% \\
34.6 \%\end{array}$ & $\begin{array}{l}5 \\
9 \\
\end{array}$ & $\begin{array}{l}35.7 \% \\
64.3 \%\end{array}$ & $\begin{array}{l}22 \\
18 \\
\end{array}$ & $\begin{array}{l}0.14 * * \\
(\mathrm{NS})\end{array}$ \\
\hline Pallor & $\begin{array}{l}\text { Absent } \\
\text { Present }\end{array}$ & $\begin{array}{l}15 \\
11\end{array}$ & $\begin{array}{l}57.7 \% \\
42.3 \%\end{array}$ & $\begin{array}{l}12 \\
2\end{array}$ & $\begin{array}{l}85.7 \% \\
14.3 \%\end{array}$ & $\begin{array}{l}27 \\
13\end{array}$ & $0.09 \#$ (NS) \\
\hline Jaundice & $\begin{array}{l}\text { Absent } \\
\text { Present }\end{array}$ & $\begin{array}{l}21 \\
5\end{array}$ & $\begin{array}{l}80.8 \% \\
19.2 \%\end{array}$ & $\begin{array}{l}12 \\
2\end{array}$ & $\begin{array}{l}85.7 \% \\
14.3 \%\end{array}$ & $\begin{array}{l}33 \\
7\end{array}$ & $1.00 \#(\mathrm{NS})$ \\
\hline
\end{tabular}

Respiratory distress was present in 12(46.2\%) and absent in 14(53.8\%) neonates of those who recovered. Among 14 neonates who died 12(85.7\%) neonates had and $2(14.3 \%)$ did not have respiratory distress. P value 0.04 for presence of respiratory distress was statistically significant.

Among the recovered neonates abdominal distension was present in 6(23.1\%) and absent in 20(76.9\%) neonates. It was present in $8(57.1 \%)$ and absent in $6(42.9 \%)$ neonates of those who died. p value 0.04 was significant.

\subsection{Investigation Profile}

Blood investigations and CSF analysis has no stastistically significant prognostic value except WBC count,lowWBCcount had a statisticaiiy significant $\mathrm{p}$ value( 0.03$)$ for mortality

TABLE - 7

\subsection{Radio Imaging Studies}

\begin{tabular}{|c|c|c|c|c|c|c|c|}
\hline \multirow{3}{*}{ Variable } & \multirow{3}{*}{ Category } & \multicolumn{2}{|c|}{ Recovered } & \multicolumn{2}{|c|}{ Expired } & \multirow{3}{*}{$\begin{array}{l}\text { Total } \\
(n=40)\end{array}$} & \multirow{3}{*}{ P Value } \\
\hline & & No & $\%$ & No & $\%$ & & \\
\hline & & \multicolumn{2}{|c|}{$(\mathbf{n}=\mathbf{2 6})$} & \multicolumn{2}{|c|}{$(n=14)$} & & \\
\hline USG Cranium & $\begin{array}{l}\text { Normal } \\
\text { Ventricle } \\
\text { Dilatation }\end{array}$ & $\begin{array}{l}21 \\
5\end{array}$ & $\begin{array}{l}80.8 \\
19.2\end{array}$ & $\begin{array}{l}10 \\
4\end{array}$ & $\begin{array}{l}71.4 \% \\
28.6 \%\end{array}$ & $\begin{array}{l}31 \\
9\end{array}$ & $0.69 \#(\mathrm{NS})$ \\
\hline $\begin{array}{l}\text { Chest } \\
\text { Radiograph }\end{array}$ & $\begin{array}{l}\text { Normal } \\
\text { Broncho Pneumonia }\end{array}$ & $\begin{array}{l}22 \\
3\end{array}$ & $\begin{array}{l}84.6 \\
11.5\end{array}$ & $\begin{array}{l}5 \\
8\end{array}$ & $\begin{array}{l}35.7 \% \\
57.1 \%\end{array}$ & $\begin{array}{l}29 \\
11\end{array}$ & $\begin{array}{l}0.006 @ \\
\text { (Sig) }\end{array}$ \\
\hline
\end{tabular}

Sig - P value significant

NS - P value not significant

* Trend Chi - Square was used calculate the P-value 
** $\quad$ Chi - Square test with Yates correction was used to calculate the $\mathrm{P}-$ Value.

\# $\quad$ Fisher's Exact test (Z-tall) was used to calculated P-value.

@ Pearson's Chi-Square test was used to calculate the P-value.

Among 26 recovered neonates ultrasonogram of cranium was normal in $21(88.8 \%)$ and ventricular dilatation was seen in $5(19.2 \%)$ neonates. Among the dead USG of cranium was normal in $10(76.4 \%)$ and $4(28.6 \%)$ neonates had ventricular dilatation. P value 0.64 was not significant.

Presence of bronchopneumonia in neonatal meningitis found to have statistically significant $\mathrm{P}$ value 0.006. Bronchopneumonia was found in $8(67 \%)$ out of 14 neonates who died. While CXR was normal in 23 $(88.6 \%)$ out of 26 neonates who recovered.

Various variables were subjected to univariate logistic regression analysis to find out significance of variable with respect to outcome.

TABLE -8

\section{Univariate Logistic Regression Analysis}

\begin{tabular}{|l|l|l|l|l|}
\hline Significant variable & $\begin{array}{l}\text { Regression } \\
\text { coefficient }(\mathbf{b})\end{array}$ & SE (b) & P-Value & $\begin{array}{l}\text { Odds ratio } \\
\text { (95\% CI) }\end{array}$ \\
\hline CXR - Abnormal & 2.29 & 0.78 & $0.003(\mathrm{Sig})$ & $\begin{array}{l}9.90 \\
(2.14 \text { to } 45.55)\end{array}$ \\
\hline
\end{tabular}

$\mathrm{SE}$ - Standard Error

CI - confidence Interval

Note: 1 Dependent variable was "outcome" (Expired/Recovered).

Note:2 Other variables included in the analysis were age, sex, gestational age, birth weight, WBC, Hb, Platelet, RFT,NEC, CSF Protein, Gramstain, Presence of any organism in CSF and USG cranium. None of these variables were statistically significant $(\mathrm{P}>0.05)$.

Univariate regression analysis revealed that chest radiograph showing bronchopneumonia was significant variable. The $\mathrm{p}$ value was 0.003 , odds ratio was $9.90(2.14-45.55)$ with the confidence interval of 95\% analysis unveiled that bronchopneumonia was the most important risk factor predicting outcome in neonatal meningitis, it was associated with 10 times increased risk of mortality. Other variables were not statistically significant.

Various variables were also subjected to Multiple Logistic Regression analysis to find out significance of independent variable with respect to outcome.

\section{Multiple Logistic Regression analysis}

TABLE - 9

\begin{tabular}{|l|l|l|l|l|}
\hline Significant variable & $\begin{array}{l}\text { Regression } \\
\text { coefficient(b) }\end{array}$ & SE (b) & P-Value & $\begin{array}{l}\text { Odds ratio } \\
\text { (95\% CI) }\end{array}$ \\
\hline CXR - Abnormal & 1.89 & 0.81 & $0.02(\mathrm{Sig})$ & $\begin{array}{l}6.60 \\
(1.35 \text { to 32.38) }\end{array}$ \\
\hline
\end{tabular}

SE -Standard Error

CI - Confidence Interval

Note: 1 Dependent variable was "Outcome" (Expired/ Recovered).

Note: 2 Method of regression was forward stepwise addition method.

Note: 3 Other variables included in the analysis were age, sex, gestational age, birth weight, WBC, Hb, Platelet, RFT,NEC, CSF Protein, Presence of any organism in CSF and USG cranium. None of these variables were statistically significant $(\mathrm{P}>0.05)$.

Multiple logistic regression analysis revealed that an abnormal chest radiograph (Bronchopneumonia) was a significant variable. P value 0.02 was significant. Odds ratio was 6.6 with the confidence interval of $95 \%$. Analysis also revealed that the presence of bronchopneumonia independently increases the risk of mortality 6.6 times. It was considered as single most important risk factor.

\section{Discussion}

The neonate is extremely vulnerable to infections in the first 28 days of life. Death and morbidity during this period are very high. Sepsis accounts for 25-40\% of all neonatal death, meningitis can occur alone or as a part of sepsis in neonatal period. Meningitis in newborn has varied clinical presentation and a rapid and often fatal course. Hence early diagnosis of meningitis is important to influence the outcome.

This study was done with the objective of identifying the clinical profile and to find out the various risk factors which could predict mortality. Neonatal meningitis commonly affects the male neonates. Male preponderance documented in this study was comparable to James overall et al., ${ }^{(3)}$ and De, Louvois et al., ${ }^{(1)}$ who have also reported male preponderance in their study on neonatal bacterial meningitis. 
Majority of the neonates presented with features of meningitis after 7 days of life, which is comparable to the conventional observations, but is in contrast to James overall et al., ${ }^{(3)}$ because they did prospective study in 6,000 pregnant women, who were followed by Physical examination and laboratory investigation since the time of registration to postnatal period. The respective infants were also followed since birth to 7 years of age. Because of the continuous monitoring they were able to pick up meningitis in earlier age itself.

Though universally low birth weight, preterms are more affected by meningitis as evidenced by James overall et al., (3) our study showed that term, low birth infants were more affected. This could be possible explained by two factors one is that the majority of preterm infants in a developing country don't survive to develop meningitis; they may die due to some other factors like Apnea, Hypothermia, Hypoglycemia etc. Due to better caregiver environment in developed countries the survival rate of preterm neonates is improved but because of the presence of neonatal risk factors as mentioned earlier, the incidence of meningitis is more in them. The incidence of meningitis was significantly higher in low birth weight infants as has been noted in other series like Groover et al., ${ }^{4}$, Berman P.H. et al., ${ }^{6}$

The most common presenting features were non specific in nature like lethargy, poor feeding, fever, respiratory distress, irritability. The classical signs of meningitis like bulging anterior fontanelle, absent neonatal reflexes were present in lesser number as noted in several other studies like Groover et al., ${ }^{(4)}$ Mc Cracken G.H. Jr et al., ${ }^{(5)}$ and Haggery R.J. et al., ${ }^{(6)}$

Univariate analysis was done for different variables to identify the risk factor which could predict the outcome in neonatal meningitis. Age of presentation more than 14 days of life, presence of respiratory distress, Abdominal distension, WBC count less than 5000, co-existence of bronchopneumonia were significantly associated with higher mortality rate. Duration of antibiotic therapy beyond 14 days was significantly associated with better outcome.

Univariate analysis when subjected to logistic regression revealed that co - existence of bronchopneumonia associated with ten times increased risk of mortality. Multiple logistic regression analysis also revealed that an abnormal CXR in the form of bronchopneumonia is the single most risk factor for mortality. The result was consistent with various other studies like Groover et al., ${ }^{(4)}$ Berman P.H. et al., ${ }^{(6)}$

The overall mortality rate was $35 \%$ which is comparable to McCarthy A.E. et al., (7) Victor A.E et al., ${ }^{(7)}$ the overall mortality rate decreased from $60 \%$ as documented by James overall et al., ${ }^{(3)} \mathrm{J} . \mathrm{S}$. Yu et al., ${ }^{(2)}$ to $35 \%$, as reported by recent studies ${ }^{(7,8)}$ over a period of past 4 decades with the advent of newer antibiotics and early diagnosis by rapid methods.

\section{Conclusion}

The clinical picture of neonatal meningitis is diverse and non specific if there be any suspicion of meningitis, Lumbar Puncture should be performed.

Onset of illness greater than 14 days of life, presence of respiratory distress, abdominal distension with low WBC count $(<5000)$ were significantly associated with mortality.

Co- existence of bronchopneumonia is the single most important risk factor associated with 10 times increased risk of mortality.

\section{References}

[1] De Louvois J. Balckborn.J Hurley R.Harvey O. infantile meningitis in England and wales: a two year study. Archieves of disease in childhood. $1991: 66: 603-607$.

[2] J.S. Yu and A.Gravaog. Purulent meningitis in the neonatal period. Arch. Dis. Childhealth. 1963, 38:391.

[3] James C.Overall Jr.M.D. Neonatal bacterial meningitis. Journal of Paediatrics. April 1970: $76: 499$ - 511.

[4] Grooves. R.V. Sutherland. J.M and landing B.H Purulent meningitis of newborn infants. New England Journal of Medicine. 1961: $264: 1115$.

[5] MC Cracken G.H Jr. and Shinefield, H.R. Changes in the Pattern of neonatal septicemia and meningitis. American J. Dis.Child. 112: 33. 1966.

[6] Berman P.H and Banker, B.Q. Neonatal meningitis: A clinical and pathological study 29 cases. Pediatrics $38: 6,1966$.

[7] McCarthy A.E Victor G. Ramotar K. Toye B 1994 Risk factor for Acquiring ampicillin resistant enterococci and clinical outcomes at candian tertiary care hospital. Journal of clinical microbiology 32: $2671-2676$.

[8] Nulder C.J.J Van Alphen L. Zanon H.C 1984 neonatal meningitis caused by E.coli in Netherlands. Journal of infections diseases, $935-940$. 